\title{
Szempontok a jegybank mandátumának újragondolásához
}

A 2007-2008. évi globális pénzügyi válságot követően új monetáris politikai eszközök jelentek meg, egy új makropolitikai ág született a pénzügyi rendszer egészét érintő kockázatok kezelésére, $s$ új kérdések merültek fel a jegybankok alapfeladatait illetően. Ez az írás a pénzügyi stabilitás fenntartásával, a válságok megelözésével kapcsolatos jegybanki teendők kérdésével foglalkozik. Van-e a jegybanknak szerepe a pénzügyi stabilitási politika alakításában? Ha a monetáris politika pénzügyi stabilitási célokat is követ, akkor ezt az árstabilitási célnak alárendelten vagy azzal mellérendelt módon tegye? A pénzügyi stabilitási cél megjelenésével fenntartható-e egyáltalán az árstabilitás elsődlegességének elve? A hazai jegybanktörvény megfogalmazásai jól tükrözik-e a Magyar Nemzeti Bank feladatkörét és a feladatok egymáshoz viszonyított fontosságát? A tanulmány szerzője amellett érvel, hogy a globális válság tanulságai alapján indokolt a jegybank mandátumának kibővítése, az árstabilitás és a pénzügyi stabilitás két egyenrangú célként történő kezelése. A szerző a hazai jegybanktörvény ennek megfelelö tartalmú változtatására tesz javaslatot.*

Journal of Economic Literature (JEL) kód: E52, E58, G18.

A globális pénzügyi válsággal megdőlt az a korábban uralkodó közgazdasági felfogás, hogy sikeres monetáris politika esetén nem alakulhat ki rendszerszintü pénzügyi egyensúlytalanság, az egyedi válságjelenségek - bankcsődök - kezelésére pedig elegendők a mikroprudenciális eszközök. A válság alacsony árak mellett jött létre, és az infláció sok helyen azóta sem éri el az árstabilitásnak megfelelö szintet. A globális válságot követően nyilvánvalóvá vált, hogy a rendszerszintű pénzügyi zavarok megelőzésében, a pénzügyi közvetítő rendszer sokkokkal szembeni ellenálló képességének fokozásában a jegybanknak fontos szerepe van. Bebizonyosodott, hogy az

* Köszönettel tartozom Bede Sándornak, Karvalits Ferencnek, Király Júliának, Mérö Katalinnak, Mosolygó Zsuzsának, Neményi Juditnak, akik a tanulmány egy korábbi változatát elolvasták és kommentálták. Bíráló megjegyzéseik közül sokat megszívleltem, néhány vitatott kérdésben azonban tartottam magam eredeti álláspontomhoz. Természetesen engem terhel a felelősség, ha egy későbbi vita ezekben nem nekem ad igazat.

Bihari Péter közgazdász, az MNB Monetáris Tanácsának korábbi tagja (e-mail: biharip@t-online.hu). A kézirat első változata 2019. július 10-én érkezett szerkesztőségünkbe.

DOI: http://dx.doi.org/10.18414/KSZ.2019.12.1241 
árstabilitás és a sikeres monetáris politika nem elégséges a pénzügyi stabilitás biztosításához. A jegybankok új eszközök alkalmazásával - előretekintő iránymutatással, mennyiségi lazítással, intenzívebb kommunikációval stb. - válaszolnak az alacsony árak kihívására, új makropolitikai ág (makroprudenciális politika) született a pénzügyi rendszer egészét érintő kockázatok kezelésére, s egyáltalában, új kérdések merülnek fel a jegybankok alapfeladatait illetően. A régi monetáris politikai rendszer megújításra szorul, de egy új rendszer még nem született meg. Ebben az átmeneti állapotban felerősödtek azok a politikai törekvések, amelyek a jegybankokat rövid távú kormányzati gazdaságpolitikai célok szolgálatába állítanák, ami komoly veszélyekkel járhat a monetáris és a pénzügyi stabilitás érvényesülésére egyaránt. A másik veszély, hogy a jegybank egyszerre kíván árstabilitási, oktatáspolitikai, egészségpolitikai és más szakpolitikai célokat követni, amihez sem felhatalmazása, sem szakértelme, sem elegendő információja nincs. A jegybankok akkor képesek hatékonyan ellenállni a politikai nyomásgyakorlásnak és a túlterjeszkedés csábításának, ha céljaik világosak, konzisztensek, és mandátumuk összhangban áll a pénzügyi közvetítő rendszer müködésére vonatkozó legújabb ismeretekkel. Márpedig a globális pénzügyi válság tanulságai szükségessé teszik a jegybanki mandátum korrekcióját.

Ez az írás a pénzügyi stabilitás fenntartásával, a válságok megelőzésével kapcsolatos jegybanki teendők kérdésével foglalkozik. Mi a jegybank szerepe a pénzügyi stabilitási politika alakításában? Ha a monetáris politika pénzügyi stabilitási célokat is követ, akkor azt az árstabilitási célnak alárendelten vagy mellérendelt módon tegye? Az árstabilitás elsődlegességének elve fenntartható-e a pénzügyi stabilitási cél megjelenésével? Jól tükrözik-e a Magyar Nemzeti Bank feladatkörét és a feladatok egymáshoz viszonyított fontosságát a hazai jegybanktörvény megfogalmazásai? Egy új publikáció sokszor - mint jelen esetben is - a korábban képviselt személyes nézetek kisebb-nagyobb módosításával jár. Jelen írásomban amellett érvelek, hogy a globális válság tanulságai alapján indokolt a jegybank mandátumának kibővítése, az árstabilitás és a pénzügyi stabilitás két egyenrangú célként történő kezelése. A hazai jegybanktörvény ennek megfelelő tartalmú változtatására teszek javaslatot.

\section{A jegybanknak van dolga a pénzügyi stabilitással}

A globális válság előtti időszak uralkodó felfogása szerint a monetáris stabilitás (stabil és alacsony infláció) és a pénzügyi stabilitás között szoros pozitív összefüggés van. ${ }^{1}$ „Hosszú távon az árstabilitás és a pénzügyi stabilitás egymást kölcsönösen

\footnotetext{
${ }^{1}$ A pénzügyi stabilitásnak nincs általánosan elfogadott definíciója. Ebben az írásban, negatív megközelítést alkalmazva, a pénzügyi rendszert akkor tekintem stabilnak, ha nincs jelen a rendszer egészét fenyegető bankválság, nincsenek szélsőséges kamatingadozások, nincs felelőtlen kockázatvállalás, nincs túlzott hitelkiáramlás és túlzott eladósodás, továbbá az eszközárak a fundamentumokkal összhangban alakulnak. Egy pénzügyi sokknak más-más lehet a következménye a bankok ellenálló képességének függvényében. Lehet, hogy a bankok gyenge tőkemegfelelése és elégtelen likviditása azonnali csődhullámot indít el, bőséges tőkepufferek esetén pedig esetleg csak alig észrevehető profités aktivitáscsökkenés jelentkezik. Jelen cikk keretében pénzügyi instabilitáson a pénzügyi közvetítő rendszer normális működését veszélyeztető sokkok jelenlétét értem.
} 
erősítik.” (Issing [2003] 17. o.) Legszigorúbb formájában ez a tétel azt állítja, hogy az árstabilitás megteremtésével a pénzügyi stabilitás is megvalósul, ezért a jegybankoknak önálló feladatként a pénzügyi stabilitás kérdéseivel nem kell foglalkozniuk. „A jegybank minden időpillanatban az árstabilitás fenntartására törekszik. Ez a legjobb garancia arra, hogy ezzel egyidejüleg a pénzügyi stabilitás is erösödjön." (Issing [2002]) Leghatározottabban Anna J. Schwartz, valamint Michael D. Bordo és szerzőtársai fogalmaznak. Schwartz szerint „ha a jegybankok igazán elkötelezettek az árstabilitás elérésére és fenntartására, ennek az elkötelezettségnek a hozadéka [...] a jobb pénzügyi stabilitás lesz" (Schwartz [1995/1998] 39. o.). Bordo és szerzőtársai megfogalmazásában: „az a monetáris politikai rendszer, amelyik stabilan tartja az aggregált árakat, melléktermékként a pénzügyi stabilitást is előmozdítja" (Bordo és szerzőtársai [2000] 27. o.). Kétségkívül nem nehéz érvelni a fenti állítások mellett. Az árak árstabilitási szint alá esése (az árstabilitás elvesztése) a magas infláció idején keletkezett adósságok reálértékének növekedését és ezáltal a csődesemények felszaporodását (a pénzügyi stabilitás megingását) eredményezheti. A csökkenő infláció nyomában csökkenő kamatszínvonal viszont könnyen vezet túlzott hitelélénküléshez. Vagy megfordítva: a gyorsan emelkedő árak - magas jövőbeli megtérülések illúzióját keltve - könnyen válnak a fundamentumoktól elszakadó beruházások és eszközárbuborékok forrásává. Az emelkedő árak ellen védelmet kereső befektetők megnövelhetik ingatlanpiaci vásárlásaikat, ami a fundamentumoktól elszakadó áremelkedést generálhat. A túl alacsony vagy a túl magas infláció ellen fellépő monetáris politika „két legyet üt egy csapásra”: miközben a stabil árak eléréséért küzd, a pénzügyi stabilitás fenntartását is elösegíti. Ha az inflációs kilátások romlása miatt monetáris szigorításra van szükség, akkor a magasabb kamatok az esetlegesen fennálló túlzott hiteldinamikát vagy eszközár-emelkedést is fékezik. ${ }^{2}$ Az összhang azonban nem minden esetben érvényesül. Néhány publikációban már a globális válság előtt megjelent, hogy ritka kivételként és rövid távon összeütközésbe kerülhet egymással az árstabilitás és a pénzügyi stabilitás (Issing [2003], Svensson [2003], Borio-Lowe [2002]). Elöfordulhat, hogy az alacsony - de az árstabilitásnak megfelelő - kamatszint megszédíti a hitelfelvevőket. Észszerü döntésnek tünik hitelből finanszírozni részvény- és ingatlanvásárlást, ezzel hozzájárulva azok gyors árnövekedéséhez, az emelkedő eszközárak és az alacsony kamatszint pedig tovább gerjeszthetik a hitelkeresletet. A spirál végül túlzott hiteldinamika, túlzott kockázatvállalás és eszközárbuborék kialakulásához vezethet. Igaz, hogy a túlzott hiteldinamika inflációs veszélyt hordoz, ami monetáris szigorításra ösztönzi a jegybankot, de lehet, hogy a pénzügyi egyensúlytalanságok már az árstabilitást védő jegybanki beavatkozások előtt jelentkeznek. A 2007-2008. évi kataklizma óta tudjuk, hogy pénzügyi válság úgy is létrejöhet, hogy előzetesen nem szólal meg az inflációs vész-

\footnotetext{
${ }^{2}$ „...a pénzügyi piacok váratlan kiszáradása valószínűleg az aggregát kereslet visszaesésével párosul. Ilyen esetben a monetáris politikai célok és a pénzügyi stabilitás célja között összhang van, mindkettő érvényesülését a monetáris lazítás szolgálja. Fordítva pedig, a hitelfeltételek jelentős és megalapozatlan enyhülését a kibocsátás potenciálist meghaladó növekedése kíséri. Ebben az esetben a pénzügyi stabilitási megfontolások a monetáris feltételek szigorítását indokolják, amit a gazdasági stabilizációs cél is indokol." (Ferguson [2003] 11. o.)
} 
csengö. Borio-Lowe [2002] ennél messzebb megy: lehetséges, hogy éppen a sikeres monetáris politika a pénzügyi stabilitási zavarok forrása. Lehetséges, hogy a monetáris politika sikere az inflációs várakozások alacsony szinten történő horgonyzásával egyúttal a jövővel kapcsolatos túlzott optimizmust gerjeszt, ami az eszközárak és a hitelezés fundamentumoktól elszakadó növekedéséhez vezet. Az alacsony infláció nemcsak a pénzügyi stabilitás biztosítéka, hanem instabilitás forrása is lehet. Ezek elméleti megfontolások. Ami pedig a tényeket illeti: a közelmúlt gazdaságtörténete - az 1929-1933-as nagy válság, az 1997. évi ázsiai válság, az 1998. évi orosz válság, a 2000. évi dotcomválság, a 2007-2008. évi globális válság - azt tanúsítja, hogy a nagy részvénypiaci boomok és pénzügyi válságok gyakran alacsony infláció mellett alakultak ki (White [2006], Schultz [2017]).

Az árstabilitás és a pénzügyi stabilitás között rövid távon tehát lehetséges választás (trade-off), azaz elöfordul, hogy a pénzügyi stabilitás helyreállítása/megörzése csak azon az áron lehetséges, hogy a jegybank a jelenben magasabb vagy alacsonyabb kamatszintet alkalmaz annál, mint ami az árstabilitási logikából következne. ${ }^{3}$ A rövid távon hozott áldozat azonban az árstabilitás hosszú távú elérését szolgálja (mert pénzügyi stabilitás nélkül nem lehetséges árstabilitás), hosszú távon a két cél együttesen teljesül.

„Az optimális monetáris politika számára időnként elkerülhetetlen, hogy a pénzügyi rendszerben fellépő feszültségek miatt rövid időre eltérjen az inflációs célkövetéstől, annak érdekében, hogy közép- és hosszú távon megőrizhesse az árstabilitást. Ez az érv implikálja, hogy a monetáris politikai döntéseket befolyásolja a pénzügyi stabilitás állapota, ami akár döntő fontosságúvá is válhat a válság megelözése és a kilábalás biztositása érdekében." (Issing [2002])

Borio-Lowe [2002] a pénzügyi stabilitás érdekében szintén elképzelhetőnek tartja a kamatpolitikai eszközök alkalmazását. Ugyanakkor az árstabilitási mandátum elsődlegességével kapcsolatban kérdéseket kellene, hogy felvessen az, ha pénzügyi stabilitási megfontolásokból az árstabilitás által diktált követelményektől eltéríthetik a jegybanki kamatszintet. Hogyan lehet elsődleges az a cél, amit éppen alárendelnek egy másik célnak? Ha pedig hosszú távon nincs konfliktus az árstabilitás és a pénzügyi stabilitás között, akkor mi értelme az árstabilitás elsődlegességéről beszélni? Az elsődlegességnek - meghatározott körülmények között - a gazdasági növekedéssel vagy a kormányzati gazdaságpolitika támogatásával kapcsolatban van értelme, de erre a kérdésre visszatérünk.

\footnotetext{
${ }^{3}$ Pénzügyi instabilitás létrejöhet árstabilitás mellett, viszont árstabilitás aligha maradhat fenn pénzügyi stabilitás nélkül. A pénzügyi stabilitás az árstabilitásnak szükséges, de nem elégséges feltétele. Az árstabilitás a pénzügyi stabilitásnak - formállogikai értelemben - nem szükséges és nem elégséges feltétele. Azaz:

- a pénzügyi stabilitás hiánya mellett nem lehetséges árstabilitás (szükségesség),

- az árstabilitás hiánya mellett a pénzügyi stabilitás tartósan is fennmaradhat (nincs szükségesség, 4-5 százalékos infláció nem törvényszerüen vezet pénzügyi egyensúlyvesztéshez),

- árstabilitás mellett felléphet pénzügyi instabilitás (nincs elégségesség, ez a 2007-2008-as válság tapasztalata),

- pénzügyi stabilitás mellett tartósan lehetséges az árstabilitásnál magasabb infláció (nincs elégségesség).
} 
A pénzügyi stabilitás zavarai változatos mechanizmusokon keresztül és különböző irányokban téríthetik el az inflációt a jegybank által helyesnek tartott mértéktől. Egy pénzügyi válság nyomában járó reálgazdasági visszaesés túl alacsony inflációhoz vezethet. A fundamentumoktól elszakadó eszközár-emelkedésekben vagy túlzott hiteldinamikában megnyilvánuló - de még nyílt válságot nem jelentő pénzügyi instabilitás viszont előbb-utóbb a fogyasztói árak túl gyors emelkedését is maga után vonja. Ebből következően a jegybanknak árstabilitási mandátumából következően eminens érdeke füződik a pénzügyi rendszer stabilitásához. Az a globális pénzügyi válság óta már nem kérdés, hogy a jegybanknak fel kell lépnie a pénzügyi stabilitási zavarok ellen. ${ }^{4}$

Az azonban kérdés, hogy a jegybank ezt a tevékenységet hogyan végezze:

a) a monetáris politikától elkülönítve, mintegy azzal párhuzamosan, vagy

b) a makroprudenciális politikáért felelős intézmények tevékenységét kiegészítve, a monetáris politikába ágyazottan, annak részeként, kamatpolitikai eszközök felhasználásával, de az árstabilitási célnak alárendelten, vagy

c) a monetáris politikai mandátum kibővítésével, az árstabilitást és a pénzügyi stabilitást egymással egyenrangú célként kezelve.

E három versengő megközelítésre a továbbiakban mint a) „két cél - két centrum”, b) „széllel szembeni politizálás”, illetve $c$ ) „a mandátum kiszélesítése” elnevezéssel hivatkozom. Közülük az első a válság előtti magyarázatok módosított változata, a harmadik pedig alapvetően újradefiniálja a jegybank gazdaságban betöltött funkcióját (mandátumát). ${ }^{5}$

A jegybankok mindig viseltek felelősséget a pénzügyi rendszer zavartalan működéséért. Létrejöttüket nem kis részben 19. század végi, 20. század eleji pénzügyi válságok alatti likviditási zavarok, pánikreakciók, a gazdasági visszaesés csillapításának igénye indokolta. A kezdetektől létezik a végső hitelezői funkció is. Egy bajba került kereskedelmi banknak nyújtott hitellel a jegybank a pénzügyi rendszer egészének stabilitását veszélyeztető tovagyürüző hatásokat igyekszik megakadályozni, és ezzel az eszközzel is próbálja a bankrendszerbe és a fizetőeszközbe vetett bizalmat fenntartani. Hagyományosan a jegybank szerepe a pénzügyi stabilitás terén egy már bekövetkezett válság következményeinek kezelésére, „romeltakarításra” szorítkozott. Később már sok jegybank közvetlenül is vizsgálta a pénzügyi közvetítő rendszer állapotát, de ezt elsősorban az árstabilitásra, a monetáris transzmisszió eredményességére gyakorolt hatás megértése és befolyásolása miatt tették. (Az MNB 2000 óta publikál pénzügyi stabilitási jelentést.) Ekkor még érdeklődési körükön kívül maradtak azok a stabilitási kockázatok, amelyeknek nincs jelentős azonnali hatásuk az inflációs folyamatokra. Ma már a jegybankok az inflációnál tágabb perspektívából közelítenek a pénzügyi stabilitás kérdéséhez. A stabilitási kockázatok válság előtti kiiktatása (megelőzés), illetve a bankok már bekövetkezett pénzügyi sokkokkal szembeni ellenálló képességének (stressztűrő képesség) fokozása került előtérbe. A válságkezelés, válságmegelőzés, a bankok ellenálló képességének fokozása eltérő szervezeti megoldásokat és más típusú eszközök alkalmazását igényelheti. Ahogy az egészséget megtámadó kórokozóval szemben lehet az immunrendszer megerösítésével vagy a kiváltó ok (a kórokozó) kiiktatásával védekezni, úgy a gazdaság normális müködésének biztosításához is az egyik út a veszélyforrások elöfordulásának minimalizálása. Ennek a cikknek a keretében alapvetően a válságmegelőzés értelmében beszélünk a pénzügyi stabilitással kapcsolatos jegybanki magatartásról.

${ }^{5}$ Smets [2014] és Schultz [2017] ehhez hasonlóan csoportosítják a témával foglalkozó álláspontokat. 


\section{„Két cél - két döntési centrum”}

A következőkben az árstabilitás és a pénzügyi stabilitás viszonyának olyan interpretációjáról lesz szó, amely legjobban Lars E. O. Svensson munkásságához köthetö. Svensson szívesen hangsúlyozza, hogy egy intézmény feladatául csak olyan célt érdemes kitűzni, amelynek teljesítésére képes, és - a Tinbergen-elvnek megfelelően - egy eszköz helyesen csak egy cél szolgálatába állítható. A monetáris politika (jól-rosszul) képes az inflációs folyamatokat egy kitűzött cél irányába terelni, a rendelkezésére álló eszközökkel (az irányadó kamat vagy a nyílt piaci műveletek alkalmazásával) azonban nem képes a pénzügyi stabilitás fenntartására. Svensson szerint a jegybanki kamatpolitika csak alacsony hatásfokkal és számottevő negatív mellékhatásokkal képes befolyásolni a pénzügyi stabilitás állapotát.

„A kamatemelésnek csak kicsi és bizonytalan hatása van a pénzügyi válság mélységére vagy bekövetkezésének valószínüségére, míg az alacsonyabb inflációval és magasabb munkanélküliséggel jelentős költségek járnak." (Svensson [2019] 290. o.)

„[Egy kamatemelés] csak szerény mértékben fékezi a háztartások és a vállalatok hitelkeresletét, viszont jelentősen növelheti a munkanélküliséget." (Quarles [2019]) ${ }^{6}$

A pénzügyi stabilitás erősítését szolgáló intézkedések gyakran célzott szereplőkre, konkrét sérülékenység csillapítására irányulnak, a monetáris politika viszont minden ágazatra és minden gazdasági szereplőre hat, ezáltal a pénzügyi kockázatok felépülésében ártatlan szereplőket is büntetheti. Egy túlzott ingatlanpiaci áremelkedésre csak kis hatással lehet egy szolid mértékủ jegybanki alapkamat-emelés. Az érdemleges hatás eléréséhez szükséges, jelentős mértékủ kamatemelés viszont az áremelkedésben nem érintett többi szektornak okozhat vállalhatatlan mértékủ károkat (és ezáltal más típusú - vállalati csődök, a kibocsátásra gyakorolt negatív hatások miatti - pénzügyi stabilitási problémák forrása lehet).

Az árstabilitás és a pénzügyi stabilitás közötti trade-off kezelésére a svenssoni megoldás az externalizálás: a monetáris politika foglalkozzon az árstabilitással, a pénzügyi stabilitásért pedig feleljen egy erre szakosodott - jegybankon kívüli vagy a jegybankon belüli, de a monetáris politikától elválasztott - intézmény. Ha stabilitási zavarok keletkeznek, akkor ezeket a stabilitásért felelős intézménynek kell elhárítania, a monetáris politika pedig zavartalanul az árstabilitás elérésére koncentrálhat.

„A monetáris politika és a pénzügyistabilitás-politika különbözők, különböző célokkal, különböző eszközökkel és sok országban különböző felelős intézményekkel.” (Svensson [2019] 306. o.)

„A magam részéről úgy látom, hogy amennyiben pénzügyi stabilitási problémák jelentkeznek, a stabilitás biztosítása érdekében nincs más választás, mint más, a monetáris politikától különböző, elsősorban a makro- és mikroprudenciális politika (vagy más szakpolitika, mint például a lakáspolitika) használata. Ha pedig a meglévő stabilitáspolitikai

\footnotetext{
${ }^{6}$ Ezt természetesen nem mindenki osztja. Woodford [2012] éppenséggel azt hangsúlyozza, hogy még egy szerény mértékü kamatemelés is jelentős hatást gyakorolhat a vállalatok külső forrás iránti igényére.
} 
eszközök elégtelenek vagy nem elég hatékonyak, akkor nincs más választás, mint a stabilitáspolitika megerősítése és egy jobb stabilitáspolitika alkalmazása.” (Uo. 291. o.)

„...a monetáris politikát elsődlegesen az inflációs és munkanélküliségi kilátásoknak, nem pedig a pénzügyi sérülékenység állapotának kell vezérelnie.” (Quarles [2019])

Ez a munkamegosztás a korábbiakban említett „két cél - két centrum” modell. A szerepek elhatárolása az átláthatóbb müködést és a könnyebb elszámoltathatóságot is segíti. Ez pedig az egyes szakpolitikák eredményességét javítja.

A pénzügyi stabilitás fenntartásáért a makroprudenciális politika felel. Nem feladata e cikknek e politika cél- és eszközrendszerének, szervezeti felépítésének részletes bemutatása. Mondanivalónk szempontjából nincs nagy jelentősége annak, hogy jegybankon kívüli vagy jegybankon belüli a makroprudenciális politikáért fö felelősséget gyakorló intézmény. Azt azonban megjegyezhetjük, hogy a makroprudenciális politika több intézmény (felügyeleti, szabályozási hatóságok, költségvetési politikáért felelős kormányszervek) kooperációját feltételezi, és a jegybank a rendelkezésére álló szaktudás, információk, szabályalkotási jogosultságok alapján kihagyhatatlan szereplöje ennek a körnek. ${ }^{7}$

A hangsúly azon van, hogy a „két cél - két centrum” modellben a makroprudenciális politikát a monetáris politikától szervezetileg elkülönülten végzik, a monetáris politika középpontjában pedig tisztán az árstabilitás áll. Ez a megközelítés abban tér el a válság előtti magyarázatoktól, hogy elismeri a makroprudenciális politika fontosságát, de a kamatpolitika céljaiban és szabályaiban nem javasol változtatást. Miközben a „két cél - két centrum” modell lényege a szakpolitikák szétválasztása, a monetáris politika és a makroprudenciális politika a gyakorlatban könnyen összemosódhat. Erre vezethet, ha jelentős a személyi átfedés a két politika döntéshozói között.

A kölcsönhatások is ezt erősíthetik. A makroprudenciális politika lépései (gyakran) közvetlenül hatnak az inflációs kilátásokra, a monetáris politika intézkedései pedig (gyakran) befolyásolják a pénzügyi stabilitás állapotát. A tőkekövetelmények szigorítása mérsékli a hiteldinamikát, az pedig fékezi az inflációt. A hitelfelvétel jövedelmi korlátainak változtatása hatással van a lakosság hitelkeresletére, valamint ezen keresztül nemcsak az ingatlanárak, hanem a fogyasztói árak alakulására is. A kamatpolitikai döntések viszont befolyásolják a gazdasági szereplők kockázatvállalási hajlandóságát, gerjeszthetik vagy fékezhetik az eszközárak változását. A monetáris politika döntéshozói felhasználják a makroprudenciális centrumtól származó információkat, és döntésükbe beépítik a makroprudenciális politika várható lépéseinek hatását.

Szoros kooperáció mellett sem zárható ki teljességgel azonban az, hogy a monetáris politika és a makroprudenciális politika egyes intézkedései a másik eredményességét kedvezőtlenül befolyásolják. Ha például az inflációs cél logikája alapján alacsony/csökkenő kamatszint indokolt, de az alacsony/csökkenő kamatok a bankok

7 A makroprudenciális politika szereplői közötti kooperáció a jegybanki függetlenség korábbi felfogásának újragondolását is indokolja (Bihari [2017]). Ellentmondásos helyzetet teremt az, hogy a monetáris politika külső befolyástól való mentessége továbbra is az árstabilitás elérésének szükséges feltétele, miközben a makroprudenciális politika alakításában a jegybank és a kormány együttmüködő szereplök. 
kockázatvállalási hajlandóságát túlzott mértékben növelnék, akkor a makroprudenciális politika pótlólagos intézkedésekkel - a fenti példában a tőkekövetelmények szigorításával - válaszolhat a negatív hatások semlegesítésére. Előfordulhat azonban az is, hogy nincs megfelelő eszköz a negatív hatások semlegesítésére. Priorizálási dilemma elé kerülhet a jegybank: az árstabilitás elérése érdekében tudomásul veszi a - monetáris politika által okozott - stabilitási kockázatok növekedését, vagy a stabilitás fenntartása érdekében tudomásul veszi az árstabilitás átmeneti feladását vagy az árstabilitás tervezettnél későbbi elérését. A dilemma feloldására nincs általános érvényủ válasz. Kismértékű pénzügyi feszültségek oldására nem érdemes monetáris politikai kompromisszumot kötni, mert az infláció oldalán keletkező veszteségek meghaladnák a pénzügyi stabilitás oldalán keletkező nyereségeket. Egy fenyegető pénzügyi katasztrófa esetén pedig a monetáris politika döntéshozói természetesen nem ragaszkodhatnak görcsösen az árstabilitási mandátumukhoz.

Svensson [2003] a monetáris politika korlátjaként értelmezi a pénzügyi stabilitási célt, amely csak ritkán és rendkívüli körülmények között effektív. Normál körülmények között a monetáris politika saját logikája szerint, a pénzügyi stabilitás által nem korlátozva müködhet. A korlátok pénzügyi válság idején válnak effektívvé. Ekkor viszont a monetáris politikai döntéseket eltérítik a saját célfüggvénye szerinti pályától. A válság csillapítása érdekében szükség lehet a monetáris feltételek lazítására, függetlenül attól, hogy az inflációs kilátások ezt indokolják, vagy sem. A priorizálási dilemma feloldására pénzügyi válság esetén van egyértelmű válasz: a pénzügyi stabilitási cél felülírja az árstabilitási célt.

\section{„Széllel szembeni politizálás”}

A „két cél - két centrum” felfogás képviselői szerint azért van szükség makroprudenciális politikára, mert a monetáris politika egyedül nem képes a pénzügyi stabilitás fenntartására. Ez az érv azonban meg is fordítható: a makroprudenciális politika egyedül nem mindig képes a pénzügyi stabilitás biztosítására. Ha a túl alacsony infláció miatt a monetáris politika nagyon alacsony kamatszintet tart fenn, akkor maga is hozzájárul stabilitási kockázatok létrejöttéhez. Az infláció gyors csökkenése felértékeli a fennálló adósságok reálterheit, miközben a túl alacsony inflációra a monetáris politika szokásos módon kamatcsökkentéssel reagál, ami tovább élezheti a stabilitási feszültségeket. Ilyenkor tehetetlen a makroprudenciális politika. Caballero-Simsek [2019] szerint kamatpolitikai eszközökkel hatékonyan lassítható az eszközárak túl gyors emelkedése, és ezzel megelözhető vagy enyhíthető egy pénzügyi válság. Prudenciális monetáris politikának (prudential monetary policy, PMP) nevezik az ilyen indíttatású lépéseket. Az eszközárboom idején végrehajtott kamatemelés azzal az előnnyel is jár, hogy egy kialakuló válság idején nagyobb lesz a jegybank manőverezési lehetősége (kamatcsökkentési képessége) a zuhanó eszközárak megfékezésére.

Sokan olyan monetáris politikát javasolnak (például Borio-Lowe [2002], Borio és szerzötársai [2018], Woodford [2012], Caballero-Simsek [2019], Issing [2003], Smets [2014]), amelynek elsődleges célja az árstabilitás, de emellett és ennek alárendelten 
a jegybank pénzügyi stabilitási célokat is követ. A célok egymást erősítik, ugyanakkor számolnak konfliktusba kerülésük lehetőségével. Nem zárják ki, hogy bizonyos esetekben a pénzügyi stabilitás védelmében a monetáris politika a „széllel szemben” haladjon (leaning against the wind), és szigorúbb legyen annál, mint amit egyedül - pénzügyi stabilitási szempontokra tekintet nélkül - az árstabilitási cél indokolna. A magasabb kamatszint miatt alacsonyabb lesz a kibocsátás, és az infláció az árstabilitási szint alá eshet, ám ez a kisebbik rossz egy eszkalálódó pénzügyi instabilitás következményeihez képest. A trade-off azonban csak rövid távú. A monetáris politika az árstabilitás védelme miatt nem türheti meg a pénzügyi egyensúlytalanságokat. A „széllel szembeni” politizálás az infláció átmeneti kilengését okozza, későbbre tolja az árstabilitás elérését, de a pénzügyi stabilitás fenntartásával az árstabilitás hosszú távú érvényesülését szolgálja.

A monetáris politikának nem kell folyamatosan a „széllel szemben” haladnia. A pénzügyi stabilitás általában szilárd. Ilyenkor az árstabilitási cél kompromisszumok nélkül érvényesíthető, és mivel az árstabilitási és a pénzügyi stabilitási célokból egymással konzisztens lépések következnek, ezért nincs is értelme valamelyik cél elsődlegességéről beszélni a másikkal szemben. Amikor viszont stabilitási kockázatok jelentkeznek, ezek kezelésének elsődleges védvonala a makroprudenciális politika. Ilyenkor először tőkemegfelelési szabályokat, likviditásszabályozási eszközök, hitelezési korlátok, hitelfedezeti előírásokat, a jegybanki tartalék után fizetendő kamatok korrekciójára kerül sor. Az esetek többségében ez elegendő is, a monetáris politika csak a végső mentsvár (Williams [2011]). Akkor válik szükségessé kamatpolitikai eszközök alkalmazása (eltérítés az árstabilitási céllal konzisztens pályától), ha a pénzügyi stabilitás fenntartására elsődlegesen hivatott makroprudenciális politika lehetőségei kimerültek. ${ }^{8}$ Smets [2014] és általában a „széllel szembeni” politizálás képviselői a pénzügyi stabilitást a monetáris politika másodlagos céljának (secondary objective) tekintik. De lehet-e másodlagos az a cél, amely az árstabilitási céllal történő összeütközés esetén a politika meghatározó tényezője?

A jegybanki döntéshozók a tényleges gyakorlatban keletkező nyereségeket és veszteségeket mérlegelik. A döntési alternatívák a társadalmi összhaszon/összveszteség (nettó eredmény) alapján sorba rendezhetők, és ennek alapján kiválasztható a legjobb döntés. Elképzelhetö, hogy a döntéshozók egy kamatemelés mérlegelésekor arra jutnak, hogy az emelés elvetése esetén az infláció oldalán elszenvedett veszteségek nagyobbak, mint a növekedés oldalán keletkező nyereségek, és ezért érdemes a kamatot emelni. Ám számos esetben a jegybankok éppen a várható magas reálgazdasági költségek miatt tartózkodtak a szigorító lépésektől. ${ }^{9}$ Ehhez hasonlóan a társadalmi összhaszon/össz-

\footnotetext{
${ }^{8} \mathrm{Ez}$ azt is jelenti, hogy a jegybanknak komoly érdeke füződik a makroprudenciális politika megerősítéséhez. Minél eredményesebb a makroprudenciális politika a stabilitás fenntartásában, annál egyszerübb, tisztább a helyzet a monetáris politika számára, ami javíthatja az eredményességét.

${ }^{9}$ Egy-egy lépés kapcsán várható a makrogazdasági előnyöket és hátrányokat a gazdaság szereplöi (és a jegybankok döntéshozói) különbözőképpen ítélhetik meg, és különböző fontosságot tulajdoníthatnak nekik. A kormányok általában érzékenyebbek a növekedési szempontokra, ezért hajlamosabbak a növekedési veszteségek hatásának túlértékelésére és ezek alapján a jegybanki döntések megkérdőjelezésére.
} 
költség mérlegelése döntheti el, hogy a széllel szemben vagy a szél irányában érdemes haladnia a monetáris politikának. Katasztrófaközeli állapotban természetesen a pénzügyi stabilitás szempontjai határozzák meg a döntéshozatalt. Kisebb súlyú pénzügyi kockázatok esetén viszont lehet, hogy a makrogazdasági összhaszon értékelése alapján nem indokolt az árstabilitási logikától eltérni. Ez pedig azt jelenti, hogy a tényleges gyakorlatban nincs olyan célja a jegybanknak, amely minden helyzetben elsőbbséget élvez a többi céllal szemben. A mindenkori veszteségfüggvény szerinti mérlegelésnek kell eldöntenie, hogy adott pillanatban melyik cél az effektív, és melyik az alárendelt. A „két cél - két centrum” képviselői szerint az árstabilitási pályától eltérített kamatpolitikának általában több a költsége, mint a haszna (Quarles [2019], Kockerol-Kok [2019], Svensson [2016]). A „széllel szembeni” politizálás hívei ezt értelemszerűen vitatják (például Adrian-Liang [2018], Gourio és szerzőtársai [2016]).

Az elmondottak alapján indokolt a szokásos jegybanki veszteségfüggvény kibővítése egy újabb komponenssel:

$\min L_{t}=\gamma_{1}\left(\pi_{t+4}-\pi^{*}\right)^{2}+\gamma_{2}\left(y_{t}-y_{t}^{*}\right)^{2}+\gamma_{3}\left(p s_{t}-p s^{*}\right)^{2}$,

ahol az $L$ a minimalizálandó társadalmi veszteség, a $\pi^{*}$ az inflációs cél, az $y^{*}$ a potenciális növekedés, a $\pi_{t+4}$ a négy negyedév múlva várt infláció, az $y_{t}$ a $t$-edik időszaki tényleges növekedés, a $p s_{t}$ a pénzügyi rendszer tényleges állapotát kifejező mutató, a $p s^{*}$ a stabil pénzügyi rendszer mutatója, $\gamma_{1}, \gamma_{2}, \gamma_{3}$ pedig a súlyok (Vredin [2015], Woodford [2012]).

A pénzügyi stabilitás számtalan - gyakran egymással ellentétes hatást gyakorló tényezö függvénye, megjelenési formái sokrétűek, ezért mindenkori állapotát aligha lehet egyetlen számmal kifejezni. Közismert a kibocsátási rés (output gap) becslésének bizonytalansága. A stabilitási rés - $\left(p s_{t}-p s^{*}\right)^{2}$ - talán még ennél is nehezebben határozható meg. A veszteségfüggvényben való szerepeltetése ennek megfelelően inkább elvi jelentőségü, inkább egy új szempont figyelembevételét jelzi, mintsem a mutató könnyủ számszerüsíthetőségére utalna. ${ }^{10}$ Az egyes döntéshozók állásfoglalásait azonban - még ha nem is feltétlenül ezekkel a fogalmakkal írnák le gondolkodásuk folyamatát - valószínüleg a maguk által intuitív módon becsült rések (kibocsátási, inflációs, stabilitási rés) és az azokhoz rendelt súlyok vezérlik.

A kibővített veszteségfüggvényből az következik, hogy amikor kicsik a stabilitási kockázatok, akkor az össztársadalmi veszteség minimalizálására törekvő monetáris politika lépései közvetlenebbül levezethetők az inflációs és a kibocsátási rés alakulásából. Amikor nagyok, akkor a veszteségfüggvény alapján is „széllel szemben" szükséges haladni.

${ }^{10}$ A Magyar Nemzeti Bank a pénzügyi stabilitás állapotának értékelését 2012 óta a prociklikusságot és a sokkellenálló képességet mérő mutatók segítségével végzi. A részindexek aggregálásával előállított stresszindex pedig a rendszerkockázat mérésére szolgál. Azt is érdemes megjegyezni, hogy a Magyar Nemzeti Bank korábbi előrejelzéseiben használt kamatpálya - a kockázati prémium szerepeltetésén keresztül - figyelembe vette a pénzügyi stabilitási szempontokat (Krusper-Szilágyi [2013]). A kockázati prémium szerepeltetése azon a megfontoláson alapult, hogy a befektetők érzékelhetik a pénzügyi stabilitási kockázatok megnövekedését, ami a befektetéseikkel kapcsolatos hozamelvárásokban is lecsapódik. 


\section{„A mandátum újrafogalmazása”}

Brunnermeier-Sannikov [2012] és [2014] szerint az árstabilitás és a pénzügyi stabilitás szoros összefonódása (intertwined) „cáfolja azt a felfogást, miszerint a monetáris politika elsődleges célja az árstabilitás, a pénzügyi stabilitást pedig ettől függetlenül müködtetett makroprudenciális és bankszabályozási eszközökkel lehet megvalósítani” (Brunnermeier-Sannikov [2012] 377. o.). A két politika szétválasztása helyett az integrált megközelítést, a két politika kooperációját és összhangját (congruency) szorgalmazzák. ${ }^{11}$ A szerzőpáros szerint normálidőkben sem bölcs dolog, ha a jegybank kizárólag az árstabilitásra összpontosít, és ettől eltérő eszközöket és intézkedéseket csak egy válság bekövetkeztekor alkalmaz. Egyensúlytalanságok a (látszólag) nyugodt időkben alakulnak ki. Ezek megelőzése érdekében a monetáris politikának szigorúnak (anticiklikusnak) kell lennie a ciklusok felívelö szakaszában, és lazának (szintúgy anticiklikusnak) kell lennie válság idején. Ezzel összhangban Csortos Orsolya és Szalay Zoltán is annak fontosságáról beszél, hogy

„a pénzügyi ciklus fellendülése idején a monetáris politika (relatíve) szigorúbb legyen még akkor is, ha az infláció alacsony és stabil, és kevésbé agresszív, illetve perzisztens lazítást hajtson végre visszaesés idején" (Csortos-Szalay [2015] 23. o.).

A szerzőpáros szerint fontos a monetáris politika rugalmasabbá tétele, a pénzügyi stabilitási szempontok figyelembevétele, azonban

„a monetáris politikai mandátumot csak a legvégső esetben lehet megváltoztatni” (uo. 25. o.).

Azt azonban a szerzők is hangsúlyozzák, hogy a monetáris politikai stratégiát újra kell gondolni úgy, hogy annak alakításában a reálgazdasági szempontok mellett nagyobb szerepet kapjanak a pénzügyi folyamatok és a pénzügyi stabilitási kockázatok is.

Pénzügyi stabilitás hiányában nincs árstabilitás. S mivel a jegybankon kívüli más intézmények nem képesek a pénzügyi stabilitás maradéktalan érvényre juttatására, a jegybanknak - az árstabilitás érdekében - szerepet kell vállalnia a pénzügyi közvetítő rendszer zavartalan működésének biztosításában.

Ám nem csak az árstabilitásból lehet levezetni a monetáris politika pénzügyi stabilitásra vonatkozó feladatait. A jegybank legvégső célja a társadalmi jólét előmozdítása. A jegybank a rendelkezésére álló eszközök és szaktudás alapján az árstabilitás megteremtésével képes ehhez hozzájárulni. A jóléthez azonban a stabil árak mellett stabil pénzügyi rendszer is szükséges. A jegybank rendelkezésére álló eszközök ez utóbbi előmozdítását is lehetővé teszik. Azaz nemcsak az árstabilitásban betöltött szerepe alapján, hanem a társadalmi jóléthez való hozzájárulás képessége alapján („saját jogán”) is magyarázható, hogy miért követ a jegybank pénzügyi stabilitási célokat (Vredin [2015]).

\footnotetext{
${ }^{11}$ Ugyanezt képviseli Adrian-Liang [2018].
} 
Az elmondottak alapján két állítást érvényesnek tekinthetünk, és azok alapján a jegybanki mandátumra vonatkozóan egy további állítást fogalmazhatunk meg:

1. a pénzügyi stabilitást érdemes a monetáris politika céljává tenni,

2. az árstabilitás nem élvez elsőbbséget a pénzügyi stabilitással szemben.

Ebből pedig az következik, hogy a jegybank alapvető feladata (mandátuma) az árstabilitás és a pénzügyi stabilitás együttes megteremtése/fenntartása. A két cél egyenrangú. ${ }^{12}$ A monetáris politika nem helyettesíti, hanem kiegészíti a makroprudenciális politikát.

„Nincs konfliktus az árstabilitás és a pénzügyi stabilitási célok között, ezek inkább egymás kiegészítői. A monetáris politika képes mindkét cél elérésére." (Mishkin [1996] 24. o.)

Azokban az esetekben, amikor a két cél elérése nem ugyanazt a monetáris politikai választ implikálja, azt az alternatívát választja a jegybank, amelyik a legmagasabb nettó társadalmi haszonnal (legkisebb veszteséggel) jár. A pénzügyi instabilitás jeleire először a makroprudenciális politikának (tőke- és likviditási követelmények módosítása stb.) kell reagálnia. Akkor és csak akkor szükségesek stabilitást erősítő monetáris politikai lépések, ha a dedikált makroprudenciális eszközökkel a kívánt cél megvalósítása nem lehetséges, vagy ugyanaz az eredmény kisebb társadalmi költséggel is elérhető (például monetáris politikai eszközök alkalmazásával). Érdemes megjegyezni, hogy a makroprudenciális intézkedések indokoltságát - és egy kamatpolitikai lépéssel szembeni előnyét - is az össztársadalmi haszonhoz való hozzájárulás alapján indokolt megítélni. Lehetséges, hogy egy-egy tervezett makroprudenciális intézkedésnek - összehasonlítva egy kamatpolitikai lépéssel - nagyobb a kára (reálgazdasági költsége), mint a haszna (a stabilitás erősítése által). ${ }^{13}$

\section{Az MNB-törvény módosításának szükségessége}

A jegybankok céljait, eszközeit, jogosítványait a törvényhozás határozza meg, és a jegybankra vonatkozó törvény rögzíti. Ez helyes is így. A jegybank függetlensége nem a célok kijelölésének szabadságát, hanem a célok elérését szolgáló eszközök politikai befolyástól mentes használatát jelenti (Bihari [2017]). A válság óta sok országban módosították a jegybanktörvényt, és sok helyen a jegybank feladatai közé emelték a pénzügyi stabilitás biztosítását is. Jeanneau [2014] 114 ország jegybanktörvényének vizsgálata alapján azt találta, hogy a jegybank feladatai között 83 esetben szerepel a pénzügyi stabilitás. A Jeanneau által közölt listából úgy tünik, hogy ő azokat az országokat is ebbe a körbe sorolta, ahol a jegybank feladatai között említik a fizetési

\footnotetext{
${ }^{12}$ A monetáris politika nem képes a kibocsátás hosszú távú növekedési ütemének befolyásolására. Rövid távon, egy-két éves időhorizonton az ár- és pénzügyi stabilitási cél mellett azonban már reálgazdasági céllal is rendelkezik. Ilyenkor a jegybanknak olyan optimalizálási feladatot kell megoldania, aminek három célváltozója van.

${ }^{13}$ Caballero-Smisek [2019] szerint megfelelő körülmények között a prudenciális monetáris politika és a makroprudenciális politika effektivitása megegyezhet egymással.
} 
rendszer biztonságos müködtetését, ami egy jóval puhább és hagyományosan létező jegybanki funkció. Az esetek nagy részében a törvény homályban hagyja a célok viszonyát, a feladatokat felsorolásszerüen jelöli meg. ${ }^{14}$ Jeanneau húsz olyan esetet azonosított, ahol a pénzügyi stabilitás másodlagos célként szerepel, és két olyan országot talált (Malajzia és Montenegró), ahol az árstabilitás és a pénzügyi stabilitás explicit módon is egymással egyenrangú célok..$^{15}$ Jeanneau [2014]-ben Norvégia még az első csoportban szerepel, de a jegybanktörvény 2016. évi módosítása óta a norvég jegybank honlapján az olvasható, hogy „a pénzügyi stabilitás a Norges Bank egyik elsődleges célja" (www.norges-bank.no).

A magyar jegybanktörvény deklarálja az árstabilitás elsődlegességét, a pénzügyi stabilitást pedig olyan feladatként nevesíti, amely nem sértheti az elsődleges cél teljesülését. Miközben a pénzügyi stabilitási szempontok beemelése a jegybanki feladatok közé a pénzügyi stabilitás fontosságának a felismerését jelzi, addig az árstabilitás elsődlegességének hangsúlyozása és a pénzügyi stabilitás alárendelt célként történő kezelése a stabilitás szempontjainak tényleges érvényre jutását nehezíti.

„Az MNB elsődleges céljának veszélyeztetése nélkül támogatja a pénzügyi közvetítő rendszer stabilitásának fenntartását, ellenálló képességének növelését, a gazdasági növekedéshez való fenntartható hozzájárulásának biztosítását és a rendelkezésére álló eszközökkel a Kormány gazdaságpolitikáját." (2013. évi CXXXIX. törvény, 3. paragrafus, 2. bekezdés) ${ }^{16}$

Ennek a megfogalmazásnak egy lehetséges olvasata az, hogy a célok (rövid távú) konfliktusa esetén az árstabilitás élvez prioritást, és minden olyan lépés az árstabilitás veszélyeztetésének minősül, amelyik eltéríti a monetáris politikát az árstabilitási céllal konzisztens pályától. Ebben a felfogásban nem élvezhetik a jegybank támogatását azok a pénzügyi stabilitást erősítő intézkedések, amelyeknek eredményeként az árstabilitás elérése későbbre tolódik. Az árstabilitás elsődlegességének elve így valós tartalmat kap ugyan, de tényleges érvényesítése mellett nem volna lehetséges a pénzügyi stabilitást biztosító összes intézkedés meghozatala. Ezzel pedig komoly felelősség terhelné a jegybankot egy pénzügyi válság előfordulásáért. Egy rugalmasabb olvasat figyelembe veszi, hogy a pénzügyi stabilitás az árstabilitás szükséges feltétele, ezért minden olyan intézkedés, amely a pénzügyi stabilitás fenntartását szolgálja, egyben az árstabilitás elérését is elősegíti. Egy pénzügyi stabilitást védő intézkedés legfeljebb az árstabilitás elérésének időhorizontját vagy a cél elérésének reálgazdasági költségeit növeli meg, de az árstabilitás elérésének végleges/tartós ellehetetlenülését nem eredményezi. Ebben az olvasatban - hosszabb távon - a célok között nincs konfliktus, emiatt viszont nincs kivel szemben érvényesíteni az árstabilitás elsődlegességét.

${ }^{14} \mathrm{Az}$ argentin jegybanktörvény szerint például a jegybank célja az ár- és pénzügyi stabilitás, a foglalkoztatás és a társadalmi egyenlőség melletti gazdasági fejlődés előmozdítása (Charter of the Central Bank of the Argentine Republic, 2012). Az argentin jegybank 2018-ra vonatkozó éves tervében azonban az árstabilitás szerepel első helyen, a pénzügyi stabilitás a másodikon.

${ }^{15}$ A montenegrói jegybanktörvény elöírása szerint a jegybank az ár- és pénzügyi stabilitási célok sérelme nélkül támogatja a kormány politikáját.

${ }^{16}$ Ezzel azonos tartalmú megfogalmazás a szerb jegybanktörvényben található. Az euróövezeten kívüli országok jegybanktörvényeinek többségében az elsődleges cél veszélyeztetése csak a kormány gazdaságpolitikájának támogatásával összefüggésben jelenik meg. 
Így megszülethet a pénzügyi stabilitás érdekében szükséges minden intézkedés, az árstabilitás elsődlegességének elve viszont tartalom nélküli üres halmazzá válik. Az árstabilitás elsődlegességének elve mindkét olvasatban aggályos: vagy alárendelt cél a pénzügyi stabilitás, és akkor pénzügyi válságok gyakori előfordulásával kell számolnunk, vagy hatékony a pénzügyi stabilitás védelme, de akkor nem élvez elsőbbséget az árstabilitás a pénzügyi stabilitással szemben.

A jegybanktörvény idézett megfogalmazása két nagyon eltérő tartalmú dolgot mos egybe. Annak van realitása, hogy a növekedést hajszoló gazdaságpolitika támogatása összeütközésbe kerül az árstabilitással. A gazdaság túlfütöttsége, a potenciálist meghaladó növekedés az infláció tartós megemelkedéséhez vezet, ezért van alapja ilyen esetben az árstabilitás sérelméről beszélni, és az ilyen végeredményre vezető gazdaságpolitikai intézkedésekkel szemben indokolt az árstabilitásnak elsődlegességet adni. ${ }^{17} \mathrm{Az}$ elsődlegesség elve azonban nem vihető át automatikusan egy másik viszonyrendszerbe. A pénzügyi stabilitás erősítése hosszú távon nem veszélyezteti, hanem elősegíti az árstabilitás elérését. A monetáris politika mindaddig zavartalanul irányulhat az árstabilitás elérésére, amíg ezáltal nem kerül ellentmondásba a pénzügyi stabilitás követelményével. Ha viszont ez az ellentmondás létrejön, akkor - bizonyos esetekben - a „széllel szembemegy" a monetáris politika, azaz nem a pénzügyi stabilitás rendelődik az árstabilitás alá, hanem fordítva. A monetáris politika elsődleges céljának szokásos megfogalmazása meg is fordítható: a monetáris politika mindaddig árstabilitási célokat követ, amíg az nem sérti a pénzügyi stabilitás követelményeit. Ebből pedig az következik, hogy a pénzügyi stabilitással való viszonyában az árstabilitásnak nincs elsőbbsége.

Az árstabilitás elsődlegességének elve a jegybankok állami gyámság alóli függetlenné válásának idején fogalmazódott meg, és akkor a függetlenség egyik garanciális elemének számított. A politikusok rövid távú érdekei gyakran összeütközésben állnak az árstabilitás hosszú távú szempontjaival, ezért a kormányzati gazdaságpolitika fenntartások nélküli, minden korlátozás nélküli kiszolgálása sértheti a jegybankok alapfeladatának sikeres ellátását. Ez továbbra is igaz. A pénzügyi stabilitással szemben azonban szükségtelen és káros az elsődlegesség érvényesítése. A pénzügyi stabilitás nem rontja, hanem javítja az árstabilitás megvalósulásának esélyét. Nem kis kommunikációs nehézséget okozhat a „széllel szembeni” döntések esetén annak elmagyarázása, hogy az elsődleges cél most éppen miért másodlagos, és ami másodlagos, az ugyanúgy teljesül hosszú távon, mint ami elsődleges. Jobban kommunikálható és a jegybank mozgásterét is bővíti, ha a jegybanktörvény alá- és fölérendeltségek helyett egymás mellé rendelt célokról beszél.

A jegybanki mandátum kibővítése és az elsőbbségi elv kiiktatása nem jelenti a jegybank árstabilitás iránti elkötelezettségének mérséklődését, és nincs ellentmondás az

\footnotetext{
${ }^{17}$ Jelen írás a monetáris és pénzügyi stabilitási célok hierarchiáját vizsgálta. Nagy szükség van azonban az árstabilitási és növekedési (foglalkoztatási) jegybanki célok viszonyának újbóli átgondolására is. Egy ezzel foglalkozó önálló tanulmány tud választ adni arra a kérdésre, hogy - a növekedéssel kapcsolatban - fel kell-e cserélni az árstabilitás elsődlegességének elvét a növekedési és árstabilitási célok egyenrangúságának elvével. Meg kell vizsgálni, hogy mikor képződik nagyobb össztársadalmi haszon: növekedésélénkítő intézkedésekkel, amelyek az árstabilitás későbbi elérését eredményezik, illetve az árstabilitás mihamarabbi elérésével, ami viszont pótlólagos reálgazdasági költségekkel (növekedési veszteséggel) jár. Nagyon úgy tűnik, hogy erre nincs általános érvényű válasz.
} 
inflációs célkövetési rendszer alkalmazásával sem. A rugalmas célkövetés eddig is az árstabilitási és reálgazdasági szempontok együttes mérlegelése alapján müködött. A pénzügyi stabilitási cél megjelenésével ez a mérlegelési kör bővül, a szükséges rugalmasság foka nő, a döntéshozatal bonyolultabbá válik, de a pénzügyi rendszer jellemzően stabil állapota következtében a tényleges monetáris politikai gyakorlatban látványos változások nem várhatók.

\section{Hivatkozások}

Adrian, T.-Liang, N. [2018]: Monetary Policy, Financial Conditions, and Financial Stability. International Journal of Central Banking, január, 73-131. o. https://doi.org/10.2139/ ssrn.2495074.

BiHARi PÉTER [2017]: A jegybanki függetlenség és elszámoltathatóság a globális válság elött és után. Közgazdasági Szemle, 64. évf. 6. sz. 573-593. o. https://doi.org/10.18414/ ksz.2017.6.573.

Bordo, M. J.-Dueker, M. C.-Wheelock, D. C. [2000]: Aggregate Price Shocks and Financial Instability: An Historical Analysis. NBER Working Paper, No. 125. https://doi. org/10.3386/h0125.

BorIo, C. [2014]: Monetary policy and financial stability: what role in prevention and recovery. BIS Working Papers, No. 440. https://www.bis.org/publ/work440.pdf.

Borio, C.-Lowe, P. [2002]: Asset prices, financial and monetary stability: exploring the nexus. BIS Working Papers, No. 114. https://doi.org/10.2139/ssrn.846305.

Borio, C.-Disyatat, P.-Juselius, M.-Rungcharoenkitku, P. [2018]: Monetary policy in the grip of a pincer movement. BIS Working Papers, No. 706. https://www.bis.org/publ/ work706.pdf.

Brunnermeier, M.-Sannikov, Y. [2012]: Redistributive monetary policy. Economic Policy Symposium. Jackson Hole, Federal Reserve Bank of Kansas City, https://scholar.princeton. edu/sites/default/files/04c\%20Redistributive\%20Monetary\%20Policy.pdf.

Brunnermeier, M.-SANnikov, Y. [2014]: Monetary analysis: price and financial stability. ECB Forum on Central Banking, május, https://scholar.princeton.edu/sites/default/ files/05c\%20ECB\%20Sintra\%20BruSan_0.pdf.

Caballero, R.-Simsek, A. [2019]: Prudential Monetary Policy. NBER Working Paper, No. 25977. https://doi.org/10.3386/w25977.

Csortos Orsolya-Szalay Zoltán [2015]: A globális pénzügyi válság kezelésének nehézségei: elméleti és gazdaságpolitikai tanulságok. Hitelintézeti Szemle, 14. évf. 3. sz. 5-38. o. http://epa.oszk.hu/02700/02722/00073/pdf/EPA02722_hitelintezeti_szemle_ 2015-3_005-038.pdf.

Ferguson, R. [2003]: Should Financial Stability Be An Explicit Central Bank Objective? Monetary Stability, Financial Stability and the Business Cycle: Five Views. BIS Working Papers, No. 18. 7-15. o. https://doi.org/10.2139/ssrn.1188107.

Gourio, F.-Kashyap, A. K.-Sim, J. [2016]: The Tradeoffs in Leaning against the Wind. NBER Working Paper, No. 23658. https://doi.org/10.3386/w23658.

IssinG, O. [2002]: Why stable prices and stable markets are important and how they fit together. First Conference of the Monetary Stability Foundation. Frankfurt/Main, december 5. European Central Bank, https://www.ecb.europa.eu/press/key/date/2002/html/ sp021205.en.html. 
IssING, O. [2003]: Monetary and financial stability: is there a trade-off? Megjelent: Monetary Stability, Financial Stability and the Business Cycle: Five Views. BIS Working Papers, No. 18. 16-23. o. https://doi.org/10.2139/ssrn.1188107.

JEANNEAU, S. [2014]: Financial stability objectives and arrangements - what's new? Megjelent: Mohanty, M. S. (szerk.): The role of central banks in macroeconomic and financial stability. BIS Working Papers, No. 76. 47-58. o. https://www.bis.org/publ/bppdf/bispap76.pdf.

Kockerol, T.- KoK, C. [2019]: "Leaning against the wind." Macroprudential Policy and the Financial Cycle. Norges Bank Working Paper, No. 1. https://doi.org/10.2139/ssrn.3334957.

Krusper Balázs-Szilágyi Katalin [2013]: Hogyan jelenhetnek meg a reálgazdasági szempontok egy kamatszabályban? MNB-Szemle, május, 43-51. o. https://www.mnb.hu/ letoltes/mnb-szemle-201305.pdf.

Mishrin, F. [1996]: What Monetary Policy Can and Cannot Do. Megjelent: Monetary Policy in Transition in East and West: Strategies, Instruments and Transmission Mechanism. Oesterreichische Nationalbank, Bécs, 13-34. o.

Quarles, R. [2019]: Monetary Policy and Financial Stability. Előadás a Developments in Empirical Macroeconomics címü konferencián. Federal Reserve Board és Federal Reserve Bank of New York, Washington, DC, május 30. https://www.federalreserve.gov/newsevents/ speech/quarles20190530a.htm.

Schultz, D. [2017]: Too Little, Too Late: How Central Bankers' Beliefs Influence What They Do. Phd-disszertáció. European University Institute, Department of Political and Social Sciences, Firenze.

Schwartz, A. J. [1995/1998]: Why financial stability depends on price stability. Economic Affairs, Vol. 15. No. 4. 21-25. o. Újraközölve: Wood, G. (szerk.): Money, Price and the Real Economy. Edward Elgar, Cheltenham-Northampton, 34-41. o. https://doi. org/10.1111/j.1468-0270.1995.tb00493.x.

Smets, F. [2014]: Financial Stability and Monetary Policy: How Closely Interlinked? International Journal of Central Banking, június, 263-300. o. https://www.ijcb.org/journal/ ijcb14q2a11.pdf.

Svensson, L. E. O. [2003]: Monetary Policy and Real Stabilization. NBER Working Paper, No. 9486. https://doi.org/10.3386/w9486.

Svensson, L. E. O. [2016]: Cost-Benefit Analysis of Leaning Against the Wind. NBER Working Paper, No. 21902. https://doi.org/10.3386/w21902.

Svensson, L. E. O. [2019]: The Relation between Monetary Policy and Financial-Stability Policy. Megjelent: Aguirre, A.-Brunnermeier, M.-Saravia, D. (szerk.): Monetary Policy and Financial Stability: Transmission Mechanisms and Policy Implications. Banco Central de Chile, Santiago de Chile, 283-311. o. https:/www.bcentral.cl/documents/145129/1247766/serie_banca_ central_v26.pdf/e7ab7621-891b-2de9-e3fe-c601e2adf673?t=1559771048660.

VREDIN, A. [2015]: Inflation targeting and financial stability: providing policymakers with relevant information. BIS Working Papers, No. 503. https:/www.bis.org/publ/work503.pdf.

White, W. [2006]: Is Price Stability Enough? BIS Working Papers, No. 205. https://doi. org/10.2139/ssrn.900074.

Williams, J. [2011]: Monetary Policy in an Era of Crises. International Monetary Fund Annual Research Conference, Washington, DC, november, https://www.frbsf.org/ourdistrict/files/john-williams-1111.pdf.

Woodford, M. [2012]: Inflation Targeting and Financial Stability. NBER Working Paper, No. 17967. https://doi.org/10.3386/w17967. 